\title{
Corn Cob as a Potential Feedstock for Slow Pyrolysis of Biomass
}

Adilah Shariff, Nur Syairah Mohamad Aziz, Nur Ismiza Ismail and Nurhayati Abdullah

School of Physics, Universiti Sains Malaysia, 11800 USM Pulau Pinang, Malaysia

*Corresponding author: syairahaziz_energyusm@yahoo.com

Published online: 25 August 2016

To cite this article: Shariff, A. et al. (2016). Corn cob as a potential feedstock for slow pyrolysis of biomass. J. Phys. Sci., 27(2), 123-137, DOI: 10.21315/jps2016.27.2.9

To link to this article: http://dx.doi.org/10.21315/jps2016.27.2.9

\begin{abstract}
The aim of this study is to investigate the characteristic of corn cob as a biomass feedstock for slow pyrolysis process. This was achieved by using proximate, elemental and thermogravimetric (TG) analysis as well as heating value, $p H$ and lignocellulosic determination. Proximate analysis was performed using ASTM E1756-01, ASTM E1755-01 and ASTM E872-82. Proximate analysis showed that the corn cob feedstock contained $87.76 \mathrm{mf} w \mathrm{w} \%$ of volatile matter, $1.05 \mathrm{mf} w \mathrm{w} \%$ of ash content and $11.09 \mathrm{mf} w \mathrm{t} \%$ of fixed carbon. The elemental analysis revealed that corn cob feedstock contain less than $1 \mathrm{mf} w t \%$ of nitrogen and sulfur. The percentages of cellulose, hemicelluloses and lignin of corn cob feedstock are 45.88\%, 39.40\% and $11.32 \%$ respectively. The weight loss of corn cob feedstock was prominent in the temperature range of $250^{\circ} \mathrm{C}-350^{\circ} \mathrm{C}$. Two distinct peaks of derivative thermogravimetric (DTG) curve indicate the difficulty of corn cob feedstock to degrade due to its high fixed carbon content. The overall findings showed that corn cob is suitable to be used as the feedstock for slow pyrolysis because of its high volatile matter and low percentages of nitrogen and sulfur. Its high fixed carbon makes it a potential feedstock for the slow pyrolysis of biomass.
\end{abstract}

Keywords: Biomass, corn cob, characteristics, slow pyrolysis, feedstock

\section{INTRODUCTION}

Pyrolysis is the thermal decomposition of biomass to produce a mixture of condensable liquids (bio-oil), gases and solid residue (biochar) in the absence of oxygen. ${ }^{1}$ The pyrolysis process can be classified into three main classes, namely slow pyrolysis, fast pyrolysis and flash pyrolysis. ${ }^{1-4}$ Each class can be differentiated by their operating conditions such as temperature, heating rate and holding time. The reaction temperature range is between $300^{\circ} \mathrm{C}-700^{\circ} \mathrm{C}$ for slow pyrolysis, $400^{\circ} \mathrm{C}-650^{\circ} \mathrm{C}$ for flash pyrolysis and $550^{\circ} \mathrm{C}$ and above for fast 
pyrolysis. ${ }^{4-6}$ Slow pyrolysis is performed at slow heating rate of between $10^{\circ} \mathrm{C}$ $\min ^{-1}$ and $20^{\circ} \mathrm{C} \min ^{-1}$. Meanwhile, fast pyrolysis takes place at much higher heating rates than slow pyrolysis. ${ }^{3,5}$ Slow pyrolysis requires long holding time of at least $30 \mathrm{~min}$ to several hours for the feedstock to fully pyrolyse while fast pyrolysis is complete in as little as two seconds. ${ }^{4,7}$ Flash pyrolysis requires shorter holding times than fast pyrolysis. ${ }^{3}$ Slow pyrolysis gives maximum yield of biochar and gas but produce less liquid, while fast and flash pyrolysis produce higher liquid yields. ${ }^{2,3}$

The different parameters of the pyrolysis process influence the yield percentage and also the properties of the product. Besides, the properties of the feedstock used for the pyrolysis also will influence the percentage yield and properties of the product. ${ }^{8}$ Various types of biomass have been used as the feedstock for slow pyrolysis process in different product applications. Oil palm wastes such as empty fruit bunches, ${ }^{9,10}$ oil palm shell ${ }^{11,12}$ and pressed fruit fibers, ${ }^{13}$ cassava wastes ${ }^{14}$ rice husk, ${ }^{15}$ rubber wood sawdust ${ }^{16}$ and wheat straw ${ }^{17}$ are among the common feedstocks used for the slow pyrolysis process. In Malaysia, corn residues are an abundant waste which are easily available throughout the year. In 2012, the production of corn in Malaysia was 52,481 tons, and in the subsequent year, it increased by about 5\% to 55,000 tons. In 2013, Malaysia ranked 113 out of 165 corn producing countries. ${ }^{18}$ Planted corn in the state of Kedah is 526 hectares while the area of the District Kubang Pasu is 187 hectares. For one hectare of land, 40,000 corns can be grown and the cost of planting one hectare of corn is RM 5,600. ${ }^{19}$ District Kubang Pasu has been voted as the Best Group National Corn in 2011. ${ }^{19}$ For every $1 \mathrm{~kg}$ of dry corn grains produced, about $0.15 \mathrm{~kg}$ of cobs, $0.22 \mathrm{~kg}$ of leaves and $0.50 \mathrm{~kg}$ of stalks are produced. ${ }^{20}$ Usually, the corn wastes such as corn cob and corn stovers are left on the ground of the farm or found littering the streets of the stall or market. ${ }^{21}$

Liu et al..$^{22}$ used corncob in their study as the feedstock of biochar production at pyrolysis temperatures ranging from $300^{\circ} \mathrm{C}$ to $600^{\circ} \mathrm{C}$. In the feedstock characterisation, they found that corn cob has higher volatile matter and fixed carbon; $69.5 \mathrm{wt} \%$ and $15.9 \mathrm{wt} \%$ respectively compared to cornstalk; $65.3 \mathrm{wt} \%$ and $15.6 \mathrm{wt} \%$ respectively. But, the corn cob contained much lower ash content, $2.9 \mathrm{wt} \%$ than the corn stalk, $11.7 \mathrm{wt} \%$. For the lignocellulosic component, it was observed that the corn cob feedstock contained higher hemicellulose of $39.3 \%$ and lower cellulose and lignin, $28.75 \%$ and $19.6 \%$ respectively. However, Demirbas $^{23}$ and Medic et al. ${ }^{24}$ found that cellulose is the main lignocellulosic component in the corn cob; $52 \mathrm{daf} w \mathrm{t} \%$ and $45.2 \mathrm{wt} \%$ respectively.

The percentage of $\mathrm{C}, \mathrm{H}, \mathrm{N}, \mathrm{S}$ and $\mathrm{O}$ are determined from the elemental analysis. From the literature of corn cob characterisation, it could be observed that carbon 
is the major element in the corn cob feedstock. The percentage of carbon in the corn cob feedstock ranges from $47 \mathrm{wt} \%$ to $49 \mathrm{wt} \%{ }^{23,25,26}$ The corn cob feedstock has low percentage of sulfur and nitrogen, usually below $1.0 \mathrm{wt} \%$. However, Liu et $\mathrm{al}^{22}$ reported $1.89 \mathrm{wt} \%$ of nitrogen for the corn cob feedstock. The low percentage of nitrogen and sulfur in the feedstock could contribute towards sustainable environment as lower percentage of nitrogen oxide and sulfur oxide will be released during the pyrolysis process. ${ }^{14}$

The percentage of carbon content and ash content in the feedstock also could influence the heating value of the biomass feedstock. According to Motghare et al., ${ }^{27}$ heating value is the amount of heat generated when a substance or biomass feedstock undergoes complete combustion. The biomass produces water and carbon dioxide when it is completely combusted and the generated water and water vapors contain latent heat which is given off upon condensation. ${ }^{27}$ High heating value (HHV) is the heating value which includes latent heat. In a study involving seven different types of biomass, Llorente and García ${ }^{28}$ found that five of them show that calorific values are directly proportional to the carbon content, and inversely proportional to the ash content. Literatures reported that the high heating value of the corn cob is in the range of $16.15 \mathrm{MJ} \mathrm{kg}^{-1}$ to $19.28 \mathrm{MJ}$ $\mathrm{kg}^{-1} \cdot 21,24$

Corn cob is a convenient source of biomass in Malaysia which can be used as feedstock for the production of biochar via slow pyrolysis process. Biochar produced from slow pyrolysis process can be used as soil enhancer to improve soil fertility. The application of biochar as a mitigation tool for sequestering recalcitrant carbon into agriculture soils also has been discussed recently. ${ }^{29}$ The physical and chemical properties of corn cob will greatly influence the quality of pyrolysis products as well as the yield percentage of products such as char, oil and gas. Therefore, a full understanding of the corn cob properties is essential to produce high quality biochar with high fixed carbon content. The main objective of this study is to investigate the properties of corn cob as a potential feedstock for the slow pyrolysis process.

\section{EXPERIMENTAL}

\subsection{Sample Collection and Pre-treatment}

The corn cobs originated from a farm in the District of Gurun, state of Kedah. As collected, the corn cobs were wet with a moisture content of $12.8 \mathrm{mf} w \mathrm{wt} \%$. The samples were dried in the sun for a few days to remove the moisture content so as to avoid the growth of orange fungus and grey mould. The corn cobs were dried 
again in the conventional oven at $105^{\circ} \mathrm{C}$ till their moisture content achieved less than $10 \mathrm{mf} \mathrm{wt} \%$ of moisture content. Then, the corn cobs were ground to powder and stored in air tight containers prior to the analysis.

\section{$2.2 \quad$ Feedstock Analysis}

The values of moisture content, ash content and volatile matter of corn cob were determined according to American Society for Testing and Materials, ASTM E1756-01, ASTM E1755-01 and ASTM E872-82, respectively. ${ }^{30-32}$ The average results from the proximate were presented in moisture free weight percentage $(\mathrm{mf}$ $\mathrm{wt} \%)$. The percentage of fixed carbon was calculated using Equation 1:

$$
\text { Fixed carbon }(\mathrm{mf} w \mathrm{t} \%)=100-(\mathrm{VM}+\mathrm{AC})
$$

where,

$\mathrm{VM}=$ volatile matter, and $\mathrm{AC}=$ ash content.

The elemental analysis was performed in a Perkin Elmer 2400 analyser to determine the percentage of carbon, hydrogen, nitrogen and sulphur in the corn cob. The percentage of oxygen was obtained from Equation 2:

$$
\text { Oxygen }(\mathrm{mfwt} \%)=100-(\mathrm{C}+\mathrm{H}+\mathrm{N}+\mathrm{S})
$$

where,

$\mathrm{C}=$ carbon, $\mathrm{H}=$ hydrogen, $\mathrm{N}=$ nitrogen, and $\mathrm{S}=$ sulfur.

The powdered corn cob sample was burned in a commercial Parr Adiabatic Bomb Calorimeter to determine its HHV. The lower heating value (LHV) was calculated by using Equation $3 .^{33}$

where,

$$
(\mathrm{LHV})_{\mathrm{dry}}=(\mathrm{HHV})_{\mathrm{dry}}-2.442(8.936 \mathrm{H} / 100)
$$

$\mathrm{H}=$ weight percentage of hydrogen on dry basis.

The value of $\mathrm{pH}$ of corn cob feedstock was measured using a Jenway $3015 \mathrm{pH}$ meter at room temperature. The $0.5 \mathrm{~g}$ of feedstock was dissolved in $50 \mathrm{ml}$ deionised water in a conical flask and covered with foil for about $30 \mathrm{~h}$ while stirring occasionally. To determine the lignocellulosic content, firstly, the ground sample was extracted with ethanol-benzene according to ASTM D1107-96. ${ }^{34}$ The 
percentage of lignin was determined using the extractive free sample with $72 \%$ sulfuric acid as described by ASTM D1106-96. ${ }^{35}$ The percentage of hemicelluloses was then determined from the difference between holocellulose and alpha-cellulose percentage as described by ASTM D1103-60. ${ }^{36}$

Scanning Electron Microscope (SEM) JEOL 6460 L V model was used to analyse the feedstock structure and surface topography of the feedstock. The coupled energy dispersive X-ray (EDX) analyser was used to detect the elements like silica, potassium and magnesium in the sample. The SEM was operated at $15 \mathrm{kV}$. The image was magnified around 50-5000 times. Before viewing the image, the corn cob feedstock was attached to an aluminum stub. The stub was then placed in a sputter coater to coat the sample with gold thus providing a conductive layer. The coating was performed in vacuum condition at $0.1 \mathrm{mbar}$ for $3 \mathrm{~min}$ and current $35 \mathrm{~mA}$. The stub was then placed in the sample holder of SEM. The image was thus displayed on the connecting monitor.

Thermogravimetric (TG) analysis was performed using Mettler Toledo SDTA851 TG Analyzer. The corn cob feedstock was loaded in a high purity alumina pan with approximately $5 \mathrm{mg}$ weight of the powdered sample. Nitrogen was used as a carrier gas for creating the inert environment. The heating rate was set at $5^{\circ} \mathrm{C}$ $\mathrm{min}^{-1}$ and the temperature range is between $30^{\circ} \mathrm{C}$ to $900^{\circ} \mathrm{C}$. This analysis produced two types of curves, TG curve and derivative thermogravimetric (DTG) curve. TG curve represents the change in weight of the sample as a function of temperature. The DTG curve indicates the rate of weight change, $\mathrm{dW} / \mathrm{dt}$ versus temperature.

\section{RESULTS AND DISCUSSION}

The result of proximate and elemental analysis of the corn cob is as shown in Table 1. The moisture content, ash content and volatile matter of corn cob were found to be $7.14 \mathrm{mf} \mathrm{wt} \%, 1.05 \mathrm{mf} w \mathrm{t} \%$ and $87.76 \mathrm{mf} \mathrm{wt} \%$, respectively. Due to the high volatile content in corn cob, it is suggested that corn cob is a suitable feedstock for the thermochemical conversion process such as pyrolysis. ${ }^{14}$ The high volatile matter content also makes biomass feedstock a highly reactive fuel with a faster combustion rate during devolatisation phase than other fuels such as coal. $^{37}$

From Equation 1, the fixed carbon value of the corn cob is $11.19 \mathrm{mf} w \mathrm{t} \%$. From the elemental analysis, it was observed that the corn cob feedstock consists of $43.81 \mathrm{mf} \mathrm{wt} \%$ of carbon, $6.54 \mathrm{mf} \mathrm{wt} \%$ of hydrogen, $0.77 \mathrm{mf} \mathrm{wt} \%$ of nitrogen, $0.69 \mathrm{mf} \mathrm{wt} \%$ of sulfur and $48.19 \mathrm{mf} \mathrm{wt} \%$ of oxygen. Elemental composition 
obtained from elemental analysis of the corn cob feedstock reveals that they are environmentally friendly when used as feedstock for pyrolysis process since they have low percentage of nitrogen and sulfur. The corn cobs feedstock will give off low rates of nitrogen oxide and sulphur oxide when during biochar production. ${ }^{14}$ The results from this study are also compared with the results from other literature in Table 1.

Table 1: Proximate and elemental analysis of corn cob.

\begin{tabular}{|c|c|c|c|c|c|c|}
\hline \multirow[b]{2}{*}{ Analysis } & \multirow{2}{*}{$\begin{array}{l}\text { This study } \\
(\mathrm{mf} w \mathrm{wt} \%)\end{array}$} & \multirow{2}{*}{$\begin{array}{c}\text { Demirbas }^{23} \\
(\mathrm{wt} \%)^{\mathrm{a}}\end{array}$} & \multirow{2}{*}{$\begin{array}{c}\text { Demiral et al. } \\
\qquad(\mathrm{wt} \%)^{\mathrm{a}}\end{array}$} & \multicolumn{2}{|c|}{$\begin{array}{c}\text { Trninić et al. }^{26} \\
(\mathrm{wt} \%)^{\mathrm{a}}\end{array}$} & \multirow{2}{*}{$\begin{array}{c}\text { Liu et } \\
\text { al. }^{22} \\
(\mathrm{wt} \%)\end{array}$} \\
\hline & & & & $\begin{array}{l}\text { Hawaiian } \\
\text { corn cob }\end{array}$ & $\begin{array}{l}\text { Serbian } \\
\text { corn } \\
\text { cob }\end{array}$ & \\
\hline \multicolumn{7}{|c|}{ Proximate analysis } \\
\hline $\begin{array}{l}\text { Moisture } \\
\text { content }\end{array}$ & 7.14 & - & 7.36 & - & - & 11.7 \\
\hline Ash content & 1.05 & 1.1 & 1.49 & 2.6 & 1.5 & 2.9 \\
\hline Volatile Matter & 87.76 & $84.6^{\mathrm{b}}$ & 79.58 & 79.6 & 81.1 & 69.5 \\
\hline Fixed Carbon & 11.19 & $15.4^{\mathrm{b}}$ & 11.57 & 17.8 & 17.5 & 15.9 \\
\hline \multicolumn{7}{|c|}{ Elemental analysis } \\
\hline Carbon & 43.81 & 49.0 & 49.32 & 47.0 & 47.6 & 48.12 \\
\hline Hydrogen & 6.54 & 5.6 & 5.35 & 6.4 & 6.3 & 6.48 \\
\hline Nitrogen & 0.77 & 0.5 & 0.63 & 0.5 & 0.6 & 1.89 \\
\hline Sulfur & 0.69 & - & - & 0.1 & 0.2 & - \\
\hline Oxygen & 48.19 & 43.8 & 44.70 & 43.4 & 43.9 & 43.51 \\
\hline
\end{tabular}

${ }^{a}$ Dry basis; ${ }^{b}$ Dry ash free basis

It could be observed that the ash content of the corn cob is quite low which ranges from $1.0 \mathrm{wt} \%$ to $2.9 \mathrm{wt} \%$. The low ash content in the biomass feedstock could reduce slagging and fouling in the furnace for thermochemical conversion process which caused by the alkali content in the high-ash biomass. ${ }^{38}$ For the elemental analysis, the carbon percentage is the lowest while the oxygen content in the corn cob is the highest compared to other literature values in Table 1. These variations could be due to a few factors such as different species of corn used, different weather conditions under which the corn is grown and different soil type on which corn has been cultivated. The corn cob feedstock used for this study has been grown under tropical climate. Meanwhile, from Table 1, it could be observed that the elemental properties of corn cob reported by Demirbas ${ }^{23}$ and Demiral et al. ${ }^{25}$ are almost similar. The Mediterranean climate of Black Sea region and Marmara region in Turkey is most likely to have contributed to the similarities of the elemental properties of corn cob reported by Demirbas ${ }^{23}$ and Demiral et al. ${ }^{25}$ 
The results of lignocellulosic percentage, heating values and $\mathrm{pH}$ value of corn cob feedstock are presented in Table 2 . The lignin, cellulose and hemicellulose were found to be $11.32 \%, 45.88 \%$ and $39.40 \%$, respectively. It was found that cellulose is the main component of corn cob feedstock. The cellulose, lignin and hemicelluloses will contribute to the thermal decomposition of corn cob feedstock and released of the volatiles. ${ }^{39-41}$ These three components played significant roles in determining the pyrolysis process of biomass under a given operating condition. ${ }^{40}$ Lignin is the main component responsible for the production of char. ${ }^{40}$ The feedstock with high lignin content could produce higher char yield during the pyrolysis process.

Table 2: Characteristics of corn cob.

\begin{tabular}{|c|c|c|c|c|c|c|}
\hline \multirow{2}{*}{ Analysis } & \multirow{2}{*}{$\begin{array}{l}\text { This } \\
\text { study }\end{array}$} & \multirow{2}{*}{ Demirbas $^{23}$} & \multirow{2}{*}{ Medic et al. ${ }^{24}$} & \multicolumn{2}{|c|}{$\begin{array}{l}\text { Ogunjobi and } \\
\text { Lajinde }^{21}\end{array}$} & \multirow[t]{2}{*}{ Liu et al. ${ }^{22}$} \\
\hline & & & & $\begin{array}{l}\text { White } \\
\text { corn cob }\end{array}$ & $\begin{array}{l}\text { Yellow } \\
\text { corn cob }\end{array}$ & \\
\hline \multicolumn{7}{|c|}{ Lignocellulose } \\
\hline $\begin{array}{l}\text { Cellulose } \\
\text { Hemicell }\end{array}$ & $45.88 \%$ & $52.0 \mathrm{wt}^{\mathrm{b}} \mathrm{o}^{\mathrm{b}}$ & $45.2 \%$ & $33.57 \%$ & $33.10 \%$ & $28.7 \%^{\mathrm{a}}$ \\
\hline $\begin{array}{l}\text { Hemicell } \\
\text { ulose }\end{array}$ & $39.4 \%$ & $32.5 \mathrm{wt}^{0} \mathrm{o}^{\mathrm{b}}$ & $38.3 \%$ & $\mathrm{n} / \mathrm{a}$ & $\mathrm{n} / \mathrm{a}$ & $39.3 \%{ }^{\mathrm{a}}$ \\
\hline Lignin & $11.32 \%$ & $15.5 \mathrm{wt} \%^{\mathrm{b}}$ & $10.3 \%$ & $18.32 \%$ & $13.40 \%$ & $19.6 \%^{\mathrm{a}}$ \\
\hline $\mathrm{pH}$ & 5.44 & - & - & 5.70 & 5.50 & - \\
\hline \multicolumn{7}{|c|}{ Heating values $\left(\mathrm{MJ} \mathrm{kg}^{-1}\right)$} \\
\hline HHV & 16.46 & - & 19.28 & 16.54 & 16.15 & - \\
\hline LHV & 15.03 & - & - & - & - & - \\
\hline
\end{tabular}

${ }^{a}$ Dry ash free basis; ${ }^{b}$ Dry, ash and extractive free

The results of lignocellulosic content of corn cob from this study is consistent with the findings reported by Demirbas ${ }^{23}$ and Medic et al. ${ }^{24}$ as presented in Table 2 where the cellulose is the main component of corn cob feedstock. The different locations of sample collection may result in slight variation of the chemical properties due to their diverse origin and species.

The $\mathrm{pH}$ value obtained for corn cob is 5.44 which is slightly acidic. This observation is agreement with the result by Ogunjobi et al. ${ }^{21}$ Heating value is determined to indicate the energy chemically bound in the feedstock and it is one of important property of a the feedstock which is used as fuel. ${ }^{42}$ The HHV of corn cob feedstock is $16.46 \mathrm{MJ} \mathrm{kg}^{-1}$ and the lower heating value was found to be $15.03 \mathrm{MJ} \mathrm{kg}^{-1}$. The result of HHV from this study is almost similar to the result 
reported by Ogunjobi et. al. ${ }^{21}$ The heating value of white corn cob and yellow corn cob reported by Ogunjobi et al. ${ }^{21}$ are $16.54 \mathrm{MJ} \mathrm{kg}^{-1}$ and $16.15 \mathrm{MJ} \mathrm{kg}^{-1}$ respectively. However, it could be observed that the result reported by Medic et al. $^{24}$ is slightly higher, i.e., $19.28 \mathrm{MJ} \mathrm{kg}^{-1}$. The difference in HHV value could be due to the different percentages of carbon, hydrogen and oxygen percentage in the feedstock. Carbon and hydrogen contributes positively to the heating value, while the oxygen content influence negatively. ${ }^{43}$ The corn cob feedstock reported by Medic et al. ${ }^{24}$ has higher carbon content $(47.15 \mathrm{wt} \%)$ and lower oxygen content (46.41 wt\%) than the finding from this study.

The Dulong formula could be used to provide an estimate of the higher heating value from ultimate analysis of wastes. ${ }^{44}$ According to Dulong's formula, the heat of combustion of a sample equals the heat of combustion of its elements regardless of whether it passes through one or more oxidation states. ${ }^{45}$

$$
\mathrm{Q}=337 \mathrm{C}+1442(\mathrm{H}-\mathrm{O} / 8)+93 \mathrm{~S}
$$

where,

$\mathrm{C}=$ mass percent of carbon, $\mathrm{H}=$ mass percent of hydrogen, $\mathrm{O}=$ mass percent of oxygen, $\mathrm{S}=$ mass percent of sulfur in the coal, and $\mathrm{Q}=$ higher heating value $(\mathrm{kJ}$ $\left.\mathrm{kg}^{-1}\right)$.

By using Equation 4, the energy content obtained from the elemental composition of corn cob feedstock using Dulong's formula was $14.88 \mathrm{MJ} \mathrm{kg}^{-1}$ while the HHV obtained from bomb calorimeter was $16.46 \mathrm{MJ} \mathrm{kg}^{-1}$. It can be observed that the HHV obtained from bomb calorimeter is slightly higher than the value calculated by Dulong formula. This might be due to the fact that Dulong formula is derived from elemental composition of pure molecules, where the calculated values are more prone to error. Whereas the measurements of "actual" heats of combustion by use of an oxygen bomb calorimeter are mainly the errors of the calorimeter and the corn cob feedstock moisture. ${ }^{46}$ The heating value relates to the amount of oxygen needed for complete combustion.

Figure 1 shows the SEM images of the corn cob structure for 2000 times magnification. Some irregularities can be observed. The corn cob is clearly seen to have no pores. It can also be observed that the corn cob displays cellular texture which does not have a well-defined pore structure. The corn cob could not retain water due to its less porous characteristic. ${ }^{47}$ The formation of some pores can be developed and further enhanced during the pyrolysis. ${ }^{48}$ 


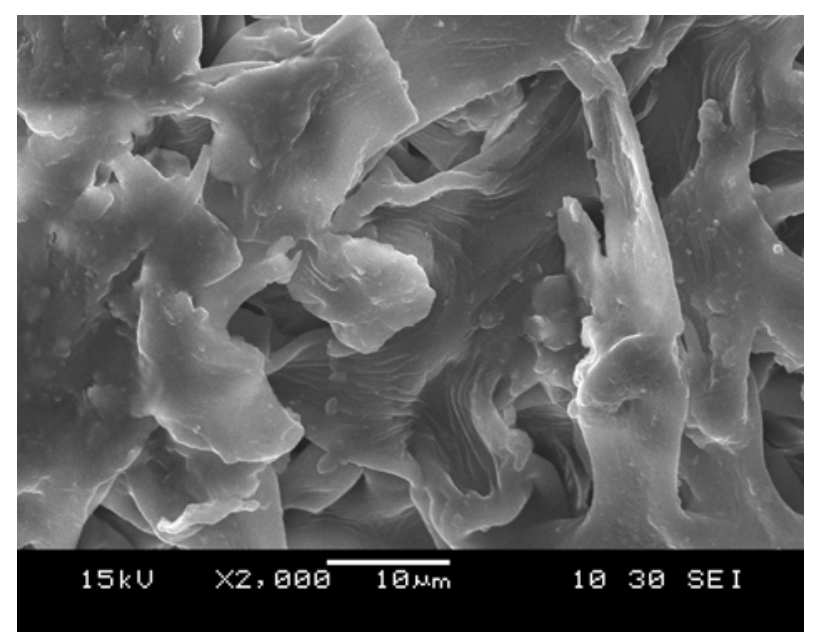

Figure 1: SEM of corn cob with 2000 times magnification.

EDX analysis was performed on corn cob. The results of EDX analysis in Table 3 shows that the composition of corn cob consists of $53.02 \%$ carbon (C), $45.85 \%$ oxygen $(\mathrm{O})$ and $1.13 \%$ silicon $(\mathrm{Si})$. The high value of carbon is good to produce high value of energy. ${ }^{14}$ Corn cob is carbohydrate in structure. Carbohydrates are imperative energy source derived by oxidation which is needed for different metabolic activities. Therefore, corn cob feedstock contained a high percentage of oxygen with respect to conventional fossil fuels including hydrocarbon (HC) liquids and char. ${ }^{49}$

Table 3: The functional groups on the corn cob surface from EDX.

\begin{tabular}{cc}
\hline Element & ${ }^{2} \%$ \\
\hline $\mathrm{C}$ & 53.02 \\
$\mathrm{O}$ & 45.85 \\
$\mathrm{Si}$ & 1.13 \\
\hline Total & 100 \\
\hline
\end{tabular}

The result of TG analysis of the corn cob was shown in Figure 2. From the TG curve, it can be seen the loss of weight in corn cob begin at temperature as low as $30^{\circ} \mathrm{C}$. Below $250^{\circ} \mathrm{C}$, the rate of weight loss is lower compared to that rate of weight loss that occur above $250^{\circ} \mathrm{C}$ and less than $350^{\circ} \mathrm{C}$. Lignin thermal decomposition occurs throughout the temperature range of $\mathrm{TG}$ analysis greater than $350^{\circ} \mathrm{C}$. From the DTG curve of Figure 3, the lowest peak is observed in the temperature range of $30^{\circ} \mathrm{C}$ to $120^{\circ} \mathrm{C}$, which occurrs due to moisture reduction in the corn cob feedstock. In fact, at $120^{\circ} \mathrm{C}$, all the moisture has been removed. 
In the temperature range of $100^{\circ} \mathrm{C}-180^{\circ} \mathrm{C}$, no obvious weight loss is observed. The DTG curve shows that the corn cob has a flat tail and two distinct peaks occurring at temperature ranges of $180^{\circ} \mathrm{C}-320^{\circ} \mathrm{C}$ and $320^{\circ} \mathrm{C}-350^{\circ} \mathrm{C}$. The first peak corresponds to the thermal decomposition of hemicelluloses and the second peak corresponds to the decomposition of cellulose. ${ }^{40,50,51}$ Hemicellulose started its decomposition easily with a maximum mass loss rate $\left(0.12 \mathrm{wt} \% \mathrm{~min}^{-1}\right)$ at $285^{\circ} \mathrm{C}$. Cellulose pyrolysis occurred at a higher temperature range between $320^{\circ} \mathrm{C}-350^{\circ} \mathrm{C}$ with the maximum weight loss rate of $0.12 \mathrm{wt} \% \mathrm{~min}^{-1}$ attained at $322^{\circ} \mathrm{C}$. ${ }^{50}$ Lignin was the most difficult to decompose. Its decomposition happened slowly at a very low mass rate. ${ }^{51}$

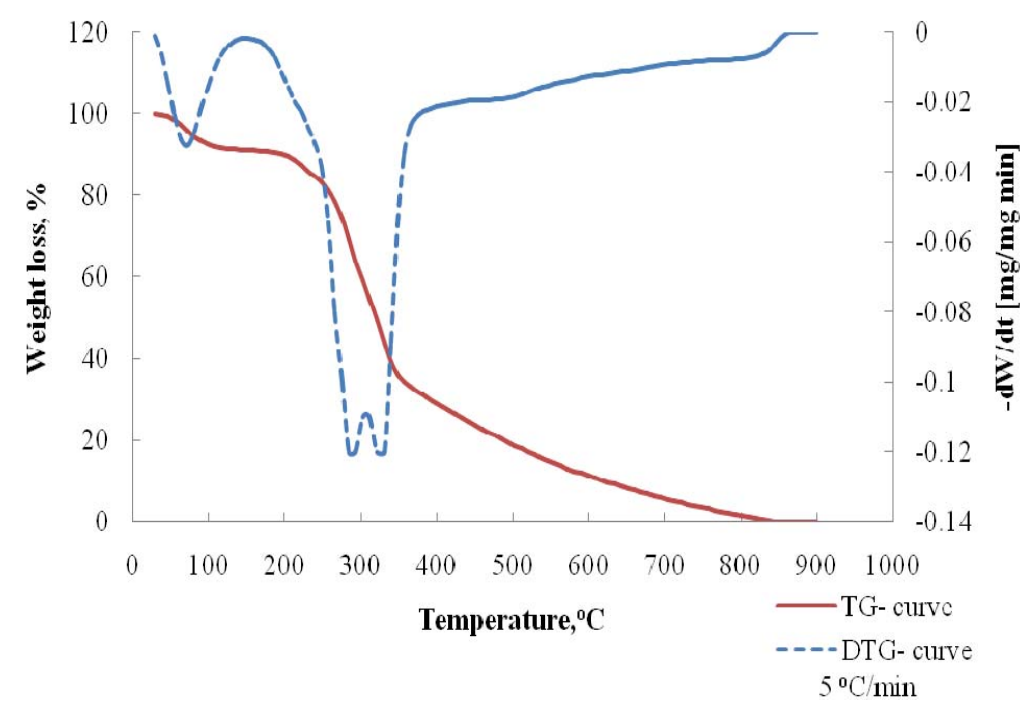

Figure 2: TG-DTG curves of the corn cob.

This study is parallel with the work by Yang et. al. who have shown that the decomposition of hemicellulose, cellulose and lignin occurred in the range of $220^{\circ} \mathrm{C}-300^{\circ} \mathrm{C}, 300^{\circ} \mathrm{C}-340^{\circ} \mathrm{C}$ and greater than $340^{\circ} \mathrm{C}$ respectively. ${ }^{40}$ The first moisture peak from DTG curve occurred at the temperature below $220^{\circ} \mathrm{C}^{43}$ Yang et al. reported that empty fruit bunches had a high volatiles content of $79.67 \mathrm{wt} \%$ and low fixed carbon content of $8.65 \mathrm{wt} \%$. The release of volatiles potentially caused an earlier degradation of carbon resulting in one big peak. ${ }^{40}$ However, corn cob feedstock is difficult to degrade due to the high value of fixed carbon content of $11.19 \mathrm{mf} w \mathrm{wt} \%$, hence resulting in two separated peaks. ${ }^{40}$ The two distinct peaks also represented the release of volatiles and the degradation of carbon that exist in the corn cob feedstock, respectively. ${ }^{40}$ 
Reactivity is the rate at which the char reacts in an oxidising or reducing atmosphere, while devolatilisation describes the easiness of char reacting with the gasification agent. ${ }^{52}$ The reactivity of the corn cob feedstock is reflective in the DTG curves. It is represented by the DTG peak height which is directly proportional to its reactivity. The temperature corresponding to the peak height is inversely proportional to the reactivity. ${ }^{43,53}$ From Figure 2, corn cob feedstock was reactive because it possess a faster pyrolysis rate with double peaks starting at a lower temperature range of $180^{\circ} \mathrm{C}-320^{\circ} \mathrm{C}$. High volatile content was also released. Vamvuka et al. ${ }^{53}$ reported that biomass such as olive kernel exhibits a simple peak with less pronounced shoulder and a more profound sloping base line was less reactive.

\section{CONCLUSION}

The abundance of corn waste in Malaysia lead to the utilisation of corn cob as the feedstock for pyrolysis process. This study has revealed the properties of corn cob. The moisture content, ash content and volatile matter of corn cob were found to be $7.14 \mathrm{mf} w t \%, 1.05 \mathrm{mf} \mathrm{wt} \%$ and $87.76 \mathrm{mf} \mathrm{wt} \%$, respectively. From the elemental analysis, the corn cob feedstock contained the highest oxygen content of $48.19 \mathrm{mf} w \mathrm{t} \%$. The percentages of hydrogen, nitrogen, carbon and sulfur composition are $6.54 \mathrm{mf} \mathrm{wt} \%, 0.77 \mathrm{mf} w \mathrm{t} \%, 43.81 \mathrm{mf} \mathrm{wt} \%$ and $0.69 \mathrm{mf}$ $\mathrm{wt} \%$, respectively. The $\mathrm{pH}$ value is slightly acidic at 5.5 . The value of lignin, hemicellulose and cellulose of corn cob were found to be $11.32 \%, 39.4 \%$ and $45.88 \%$ respectively. From the SEM analysis, the structure of corn cob appeared to be compact with no pores could be observed. The TG analysis showed that the corn cob samples started to degrade at $250^{\circ} \mathrm{C}$ and the weight loss was prominent in between $250^{\circ} \mathrm{C}$ and $350^{\circ} \mathrm{C}$. The DTG curve consist of two distinct peaks between temperature range of $180^{\circ} \mathrm{C}-320^{\circ} \mathrm{C}$ and $320^{\circ} \mathrm{C}-350^{\circ} \mathrm{C}$, which correspond to the thermal decomposition of hemicelluloses and cellulose respectively. This study found that the corn cob is suitable to be used as the feedstock for slow pyrolysis because of its high volatile matter and low percentages of nitrogen and sulfur. The high fixed carbon makes it a potential feedstock for the production of high quality biochar via slow pyrolysis process.

\section{ACKNOWLEDGEMENT}

The financial support from Universiti Sains Malaysia under the short term research grant 304/PFIZIK/6312102 and Ministry of Education Fundamental Research Grant 203/PFIZIK/6711410 are gratefully acknowledged. The authors 
would also like to thank the corn suppliers at Gurun who kindly donated the corn cob for this research.

\section{REFERENCES}

1. Sadaka, S. (2010). Pyrolysis. Retrieved from http://bioweb.sungrant.org/NR/rdonlyres/57BCB4D0-1F59-4BC3-A4DD 4B72E9A3DA30/0/Pyrolysis.pdf on 15 March 2014.

2. Kanyaporn, C. et al. (2012). Biochar production from freshwater algae by slow pyrolysis. Maejo Int. J. Sci. Technol., 6(2), 186-195.

3. Younes, C. \& Mohammed, K. (2013). Thermal conversion of biomass, pyrolysis and gasification: A review. Int. J. Eng. Sci., 2, 75-85.

4. Mark, J. C., Fiilliu, F. B. \& Arren, C. B. (2000). Flash vacuum pyrolysis of lignin model compounds. J. Org. Chem., 65(5), 1376-1389, DOI: $10.1021 /$ jo991479k.

5. Jinje, P. et al. (2014). Slow pyrolysis of rice straw: Analysis of products properties, carbon and energy yields. Biores. Technol., 155, 63-70, DOI: 10.1016/j.biortech.2013.12.084.

6. Nurhayati, A., Gerhauser, H. \& Bridgwater, A. V. (2007). Bio-oil from fast pyrolysis of oil palm empty fruit bunches. J. Phys. Sci., 18(1), 5774.

7. Steven, C. P. et al. (2013). Comparing corn stover and switchgrass biochar: Characterization and sorption properties. J. Agr. Sci., 5(1), 1-8, DOI: $10.5539 /$ jas.v5n1p1.

8. Yang, H. et al. (2006). Mechanism of palm oil waste pyrolysis in a packed bed. Energy Fuel, 20(3), 1321-1328, DOI: 10.1021/ef0600311.

9. Khor, K. \& Lim, K. (2008). Slow pyrolysis of oil palm empty fruit bunches. Int. Energ. J., 9(3), 181-188.

10. Sukiran, M. A. et al. (2011). Production and characterization of bio-char from the pyrolysis of empty fruit bunches. Am. J. Appl. Sci., 8(10), 984 988, DOI : 10.3844/ajassp.2011.984.988.

11. Abnisa, F. et al. (2013). Characterization of bio-oil and bio-char from pyrolysis of palm oil wastes. Bioenerg. Res., 6(2), 830-840, DOI: 10.1007/s12155-013-9313-8.

12. Khor, K. H. (2012). Laboratory-scale pyrolysis of oil palm shells. Paper presented at Persidangan Kebangsaan Pembangunan dan Pendidikan Lestari 2012, Institut Pendidikan Guru, Kampus Tuanku Bainun, Bukit Mertajam, Penang, 19-20 September.

13. Hooi, K. K., Alauddin, Z. A. Z. \& Ong, L. K. (2009). Laboratory-scale pyrolysis of oil palm pressed fruit fibres. J. Oil Palm Res., 21(June), 577-587. 
14. Noor, N. M., Shariff, A., \& Abdullah, N. (2012). Slow pyrolysis of cassava wastes for biochar production and characterization. Iran. J. Energ. Environ., 3, 60-65.

15. Natarajan, E. \& Ganapathy Sundaram, E. (2009). Pyrolysis of rice husk in a fixed bed reactor. Int. J. Mech. Aerosp. Ind. Mechatron. Manuf. Eng., 3(8), 959-963.

16. Shaaban, A. et al. (2014). Influence of heating temperature and holding time on biochars derived from rubber wood sawdust via slow pyrolysis. $J$. Anal. Appl. Pyrol., 107, 31-39, DOI: 10.1016/j.jaap.2014.01.021.

17. Ronsse, F. et al. (2013). Production and characterization of slow pyrolysis biochar: Influence of feedstock type and pyrolysis conditions. Glob. Change Biol. Bioenergy, 5(2), 104-115, DOI: 10.1111/gcbb.12018.

18. Factfish. (2015). Malaysia: Maize, total, production quantity (tons). Retrieved from www.factfish.com on 26 March 2015.

19. Portal Kedah. (2013). Tingkatkan produktiviti tanaman kedah. Retrieved from http://portal.kedah.gov.my on 14 April 2013.

20. Zhang, Y., Ghaly, A. E. \& Li, B. (2012). Physical properties of corn residues. Am. J. Biochem. Biotechnol., 8(2), 44-53, DOI: 10.3844/ajbbsp. 2012.44.53.

21. Ogunjobi, J. K., \& Lajide, L. (2013). Characterisation of bio-oil and biochar from slow-pyrolysed Nigerian yellow and white corn cobs. $J$. Sustain. Energy Environ., 4(2), 77-84.

22. Liu, X. et al. (2014). Characterization of corncob-derived biochar and pyrolysis kinetics in comparison with corn stalk and sawdust. Biores. Technol., 170, 76-82, DOI: 10.1016/j.biortech.2014.07.077.

23. Demirbas, A. (2004). Effects of temperature and particle size on bio-char yield from pyrolysis of agricultural residues. J. Anal. Appl. Pyrol., 72(2), 243-248, DOI: 10.1016/j.jaap.2004.07.003.

24. Medic, D. et al. (2012). The effects of particle size, different corn stover components, and gas residence time on torrefaction of corn stover. Energies, 5(4), 1199-1214, DOI: 10.3390/en5041199.

25. Demiral, İ., Eryazıc1, A. \& Şensöz, S. (2012). Bio-oil production from pyrolysis of corncob (Zea mays L.). Biomass Bioenergy, 36, 43-49, DOI: 10.1016/j.biombioe.2011.10.045.

26. Trninić, M. et al. (2012). Kinetics of corncob pyrolysis. Energy Fuel, 26(4), 2005-2013, DOI: 10.1021/ef3002668.

27. Motghare, K. A. et al. (2016). Comparative study of different waste biomass for energy application. Waste Manage., 47, 40-45, DOI: 10. 1016/j.wasman.2015.07.032.

28. Llorente, M. J. F. \& García, J. E. C. (2008). Suitability of thermochemical corrections for determining gross calorific value in biomass. Thermochim. Acta, 468(1-2), 101-107, DOI: 10.1016/j.tca.2007.12.003. 
29. Gokila, B. \& Baskar, K. (2015). Characterization of Prosofis juliflora L. biochar and its influence of soil fertility on maize in alfisols. Int. J. Plant Animal Env. Sci., 5(1), 123-127.

30. American Society of Testing and Materials (ASTM). (2006). ASTM E871-82 standard test method for moisture analysis of particulate wood fuels.. New York: ASTM International.

31. ASTM. (2006). ASTM E872-82 standard test method for volatile matter in the analysis of particulate wood fuels. New York: ASTM International.

32. ASTM. (2007). ASTM E1755-01 standard test method for ash in biomass. New York: ASTM International

33. Pattiya, A., Titioye, J. O. \& Bridgwater, A. V. (2006). Fast pyrolysis of agricultural residues from cassava plantation for bio-oil production. Paper presented at the 2nd Joint International Conference on Sustanainable Energy and Environment (SEE 2006), Bangkok, Thailand, 21-23 November.

34. ASTM. (2013). ASTM D1107-96 standard test method for ethanoltoluene solubility of wood. New York: ASTM International.

35. ASTM. (2007). ASTM D 1106-96 standard test method for acidinsoluble lignin in wood. New York: ASTM International.

36. ASTM. (2013). ASTM D 1103-60, 1978 standard test method for $\alpha$ cellulose. New York: ASTM International.

37. Poddar, S. et al. (2014). Effect of compression pressure on lignocellulosic biomass pellet to improve fuel properties: Higher heating value. Fuel, 131, 43-48, DOI: 10.1016/j.fuel.2014.04.061.

38. Abdullah, N., Sulaiman, F. \& Gerhauser, H. (2011). Characterization of oil palm empty fruit bunches for fuel application. J. Phys. Sci., 22(1), 124.

39. Danje, S. (2011). Fast pyrolysis of corn residues for energy production. Masters diss., Stellenbosch University, South Africa.

40. Haiping, Y. et al. (2004). Thermogravimetric analysis-Fourier transform infrared analysis of palm oil waste pyrolysis. Energy Fuel, 18, 1814 1821, DOI: 10.1021/ef030193m.

41. Piyarat, W., Chaiyot, T. \& Malee, T. (2011). Characterization of products from slow pyrolysis of palm kernel cake and cassava pulp residue. Korean J. Chem. Eng., 28(12), 2262-2274.

42. Erol, M., Haykiri-Acma, H. \& Küçükbayrak, S. (2010). Calorific value estimation of biomass from their proximate analyses data. Renew. Energ., 35(1), 170-173, DOI: 10.1016/j.renene.2009.05.008. 
43. Wan Ab Karim Ghani, W. A. et al. (2010). Physical and thermochemical characterisation of Malaysian biomass ashes. J. Inst. Eng. (Malaysia), 7(3), 9-18.

44. Ujam, A. J. \& Eboh, F. (2012). Thermal analysis of a small-scale municipal solid waste-fired steam generator: Case study of Enugu State, Nigeria. J. Energy Technol. Policy, 2(5), 38-54.

45. Buckley, T. J. \& Domals, E. S. (1998). Evaluation of data on higher heating values and elemental analysis for refuse-derived fuels. Paper presented at the Proceedings of National Waste Processing Conference, American Society of Mechanical Engineers, Pennsylvania, 77-84.

46. Guv, M., Claude, C. \& Tewarson, A. (1999). An analysis of some practical methods for estimating heats of combustion in fire safety studies. Paper presented in the Proceedings of 8th International Fire Science and Engineering Conference (Interflam 99), Edinburgh, 28 June1 July.

47. Shafie, S. T. et al. (2012). Effect of pyrolysis temperature on the biochar nutrient and water retention capacity. J. Purity Util. React. Environ., 1(6), 323-337.

48. Tsai, W. T. et al. (2001). Thermogravimetric analysis of corn cob impregnated with zinc chloride for preparation of activated carbon. $J$. Therm. Anal. Calorim., 63, 351-357.

49. Jenkins, B. M., Baxter, L. L. \& Miles, T. R. (1998). Combustion properties of biomass. Fuel Process. Technol., 54, 17-46.

50. Yang, H. et al. (2007). Characteristics of hemicellulose, cellulose and lignin pyrolysis. J. Fuel, 86, 1781-1788, DOI: 10.1016/j.fuel.2006.12.013.

51. Cagnon, B. et al. (2009). Contributions of hemicellulose, cellulose and lignin to the mass and the porous properties of chars and steam activated carbons from various lignocellulosic precursors. J. Biores. Technol., 100, 292-298, DOI: 10.1016/j.biortech.2008.06.009.

52. Gomes Maria, D. L. I., Eduardo, O. \& Antonio, C. F. V. (2009). Thermal analysis evaluation of the reactivity of coal mixtures for injection in the blast furnace. Mater. Res., 9(1), 91-95, DOI: 10.1590/S151614392006000100017.

53. Vamvuka, D., Pasadakis, N. \& Kastanaki, E. (2003). Kinetic modeling of coal/agricultural by-product blends.department of mineral resources engineering. J. Energy Fuels, 17, 549-558, DOI: 10.1021/ef020179u. 